\title{
THE EXPORT PERFORMANCE OF INDONESIAN DRIED CASSAVA IN THE WORLD MARKET
}

\author{
Nico Adi Putra Hutabarat ${ }^{1,2^{*}}$, Suhartini ${ }^{1}$, Wen-Chi Huang ${ }^{2}$, and Wen-I \\ Chang ${ }^{2}$ \\ ${ }^{1)}$ Master Degree in Agricultural Economics, Post Graduate Program Faculty of Agriculture, University of \\ Brawijaya \\ ${ }^{2)}$ International Master's Degree Program in Agribusiness Management, National Pingtung University of Science \\ and Technology Taiwan
}

*Corresponding Author : nickoadi@yahoo.com

\begin{abstract}
As an exporter of dried cassava, Indonesia ranks third worldwide; following Thailand and Vietnam. Indonesia was among the top four of dried cassava producers in the world; however, between year 2000 and 2015 , by average only $0.63 \%$ of the total production was exported. Indonesia needs to improve the competitiveness performance. This study investigates the growth in exports of Indonesian Cassava in the World Market. The Constant Market Share (CMS) was used to measure the growth in exports of Indonesian Cassava. Based on result of Constant Market Share (CMS), Indonesia, Thailand, and Vietnam maintained their share in the world market during the Global Economic Crisis, because the growth rates of dried cassava import relative quickly during the crisis. The import of other commodities are decreased during the crisis. But, it did not happen for dried cassava. The dried cassava export to the world survived during this crisis.
\end{abstract}

Keywords : Dried Cassava, Export Growth, Indonesia, World Market

\section{INTRODUCTION}

One of Indonesia's important commodities in the agricultural sector is cassava (Manihot esculenta Crantz). According to Suwandi (2016), cassava is one of rice food substitutes that is important in supporting the food security of the region, especially in Eastern Indonesia. In Indonesia, cassava is a third food crop commodity; following rice and corn.

Globally, Indonesia was among the top four cassava producers with an annual export growth rate of $96.21 \%$ between 2000 and 2015, while an annual growth rate of $118.22 \%$ over the same time period. Indonesia export cassava in the form of cassava flour and dry cassava. Indonesia is the third largest country exporting dried cassava in the world; Following Thailand and Vietnam (FAO, 2017; Suwandi, 2016).

Indonesia was among the top four cassava producers; However, between 2000 and 2015 from the export of cassava, on average, only $0.63 \%$ of the total production was exported (FAO, 2017). On the other hand, the three major importing countries of dried cassava in Indonesia are Malaysia, China, and the Republic of Korea. In this case, Indonesia must have competitiveness in marketing products displayed in international markets. Therefore, competitiveness becomes very important. Unlike other competitors, Thailand on average from 2000 to 2015 exports $23 \%$ of total national cassava production worldwide and Vietnam exports $9 \%$ of total national cassava production worldwide (FAO, 2017).

Regarding dried cassava market, Indonesia still needs to reobserve the position in the world market. Therefore, economic arrangement of dried cassava is needed to develop its comparative advantage. This research was conducted to find out the important factors in increasing the export performance of dried cassava in the world market.

\section{METHODS}

The analysis method of constant market shares was developed by Tyszynski in 1951. After 
that, this analysis method is extended by Learner and Stern in 1970. This method is used in order to study the relation between structural changes in world trade and to determinant the export and growth performance of individual countries (Fagerberg and Gunnar Soll E, 1985).

$\mathrm{V}^{\prime} . .-\mathrm{V} . . \equiv \sum_{\mathrm{i}} \mathrm{r}_{\mathrm{i}} \mathrm{V}_{\mathrm{i} .}+\sum_{\mathrm{i}}\left(\mathrm{V}^{\prime}{ }_{\mathrm{i} .}-\mathrm{V}_{\mathrm{i} .}-\mathrm{r}_{\mathrm{i}} \mathrm{V}_{\mathrm{i}}\right)$

$\equiv(\mathrm{rV} .)+.\sum_{\mathrm{i}}\left(\mathrm{r}_{\mathrm{i}}-\mathrm{r}\right) \mathrm{V}_{\mathrm{i} .}+\sum_{\mathrm{i}}\left(\mathrm{V}^{\prime}{ }_{\mathrm{i} .}-\mathrm{V}_{\mathrm{i} .}-\mathrm{r}_{\mathrm{i}} \mathrm{V}_{\mathrm{i} .}\right)$

(a)

(b)

(c)

This equation represents the a "two-level" analysis, in which the growth of $i$ exports is divided into parts as attributed to:

(a) The general rise in world exports

(b) The commodity composition of $\mathrm{i}$ exports in Period 1. It measures wheter the country in period 1 is focused on commodities that grew relatively fast or slowly between period 1 and period 2. If the value is positive, that means that the country has to concentrate its export on commodities with growth rates that have higher than the world average and vice versa.

(c) An unexplained residual (competitiveness effect) indicating the difference between $\mathrm{i}$ actual export increase and the hypothetical increase if $i$ had maintained its share of the exports of each commodity group. If the value is negative, that means country has failed to maintain market share in all markets for commodity (competitiveness has decreased). If the value is positive, that means the country increased the market shares in all markets for commodity (competitiveness has increased).

\section{RESULT AND DISCUSSION}

Constant Market Share (CMS) use in order to study the relation between structural changes in world trade and to determinant the export and growth performance of individual countries. This study uses annual calculation since 2000 to 2015 for other major player in exported country for dried cassava, which is Thailand and Vietnam as the competitor of Indonesia.

Figure 1 show the export changes that Indonesia, Thailand, and Vietnam did to the world.

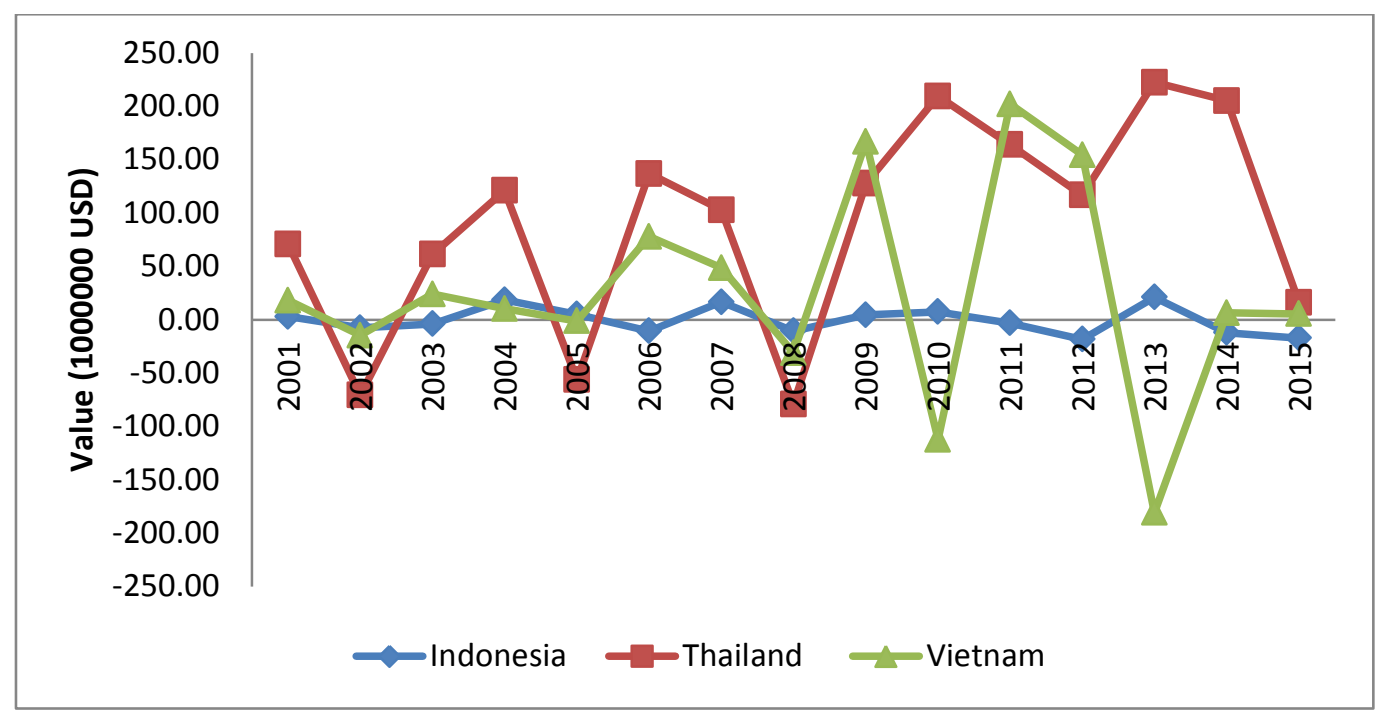

Figure 1. The Change Export of Dried Cassava

Figure 1 shows that the trend of export changes was fluctuated during each period. All countries had fluctuated performance. Indonesia also had performance fluctuation but the general tendency was constant. Different with Thailand that had extremely fluctuated. The extremely change of export value of dried cassava in period 2004-2005 in Thailand was caused by the decreasing of planting area, that affected the decreasing of production and productivity during that year (figure
1). On the other hand, during the period of 20142015 the export of dried cassava from Thailand relatively constant (different with the previous years). That's made the change of export dried cassava value during that period decreasing drastically (FAO, 2017; Piyachomkwan and Morakot, 2011).

Vietnam had the decreasing in change of export value of dried cassava in period 2012-2013. According to Ham et al. (2016), it was not because 
the decreasing of cassava harvested area or cassava production, but it was caused by the decreasing of export volume from 2012 to 2013 around $29.20 \%$. In period 2014-2015, the value of export dried cassava was constant (FAO, 2017).

The growth effect (figure 2) shows that there were fluctuation movements during period 2000-2001 to 2014-2015. Different with the change of export (figure 1) during global financial crisis 2008-2009, the growth effect from three countries have negative values, which is mean that the part of the growth of cassava have negative attributed to the overall rise in world exports. After the Global Economic Crisis, at period 2010-2011, the growth effect from three countries have positive values, which is mean that in this period the part of the growth of cassava have positive attributed to the overall rise in world exports.

However, on the other period from 20122013 to 2014-2015, the growth effect of countries did not stay constant. Although in period 20122013 the value of countries growth effects were still positive, in period 2014-2015 the value of countries growth effect back to negative. This was because after Global Economic Crisis, the total import of all commodities in the world are decreasing during that period (UN Comtrade, 2017).

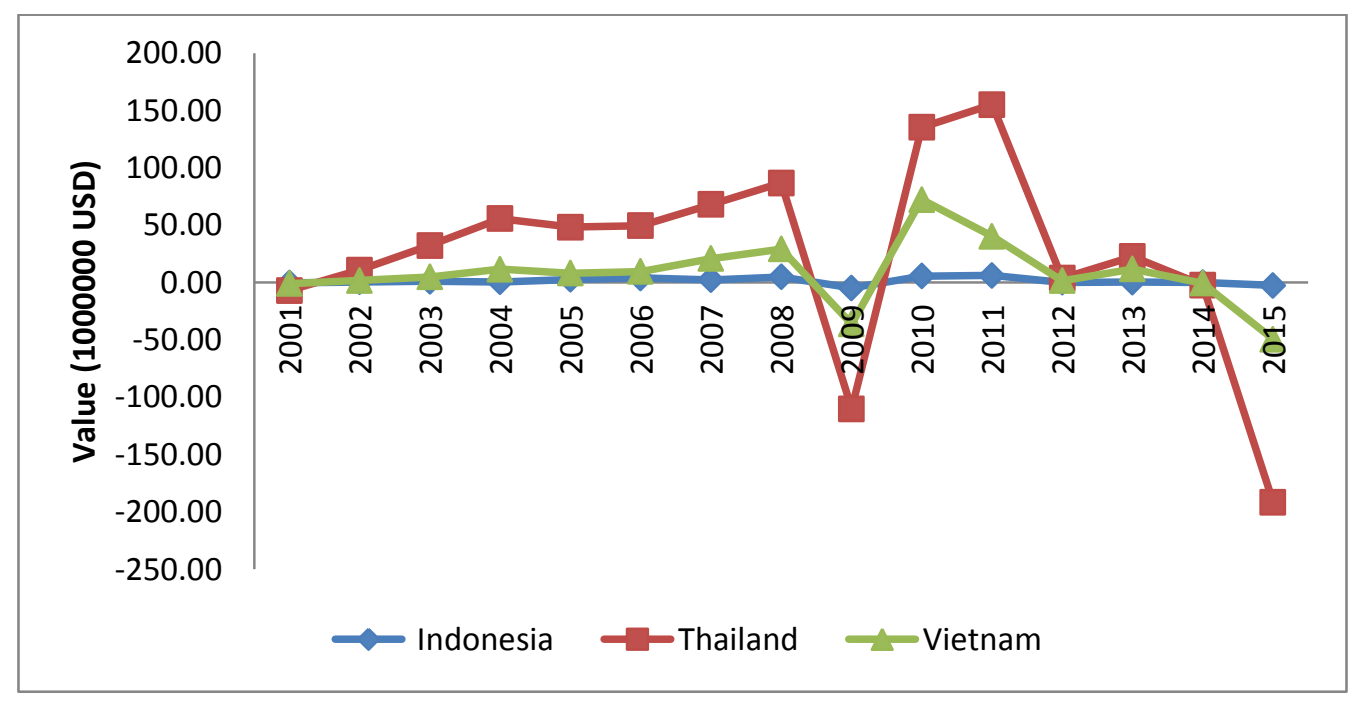

Figure 2. The Growth Effect in World Exports

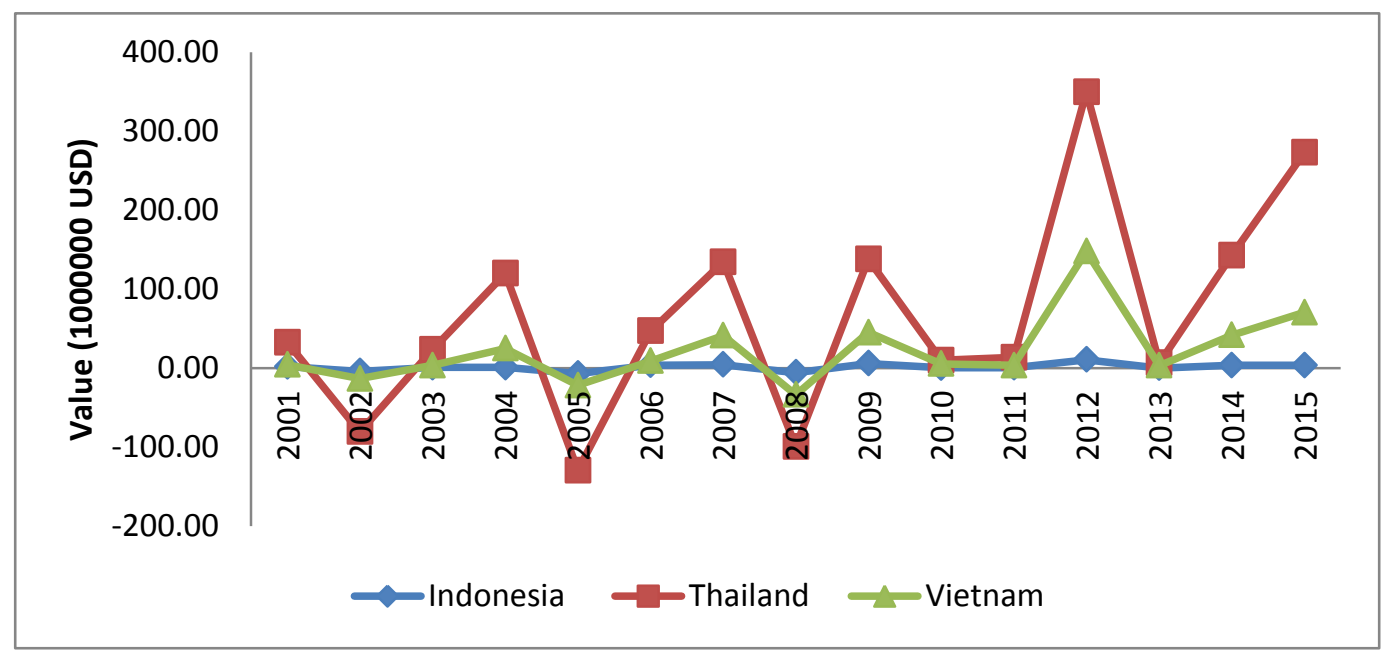

Figure 3. The Commodity Composition Effect 
Another statement about the rising of the world exports (Growth Effect), although the total import of all commodity in the world decreasing during Global Economic Crisis, the import of dried cassava during the Global Economic Crisis was constant and had an increasing tendency; this increasing import of dried cassava happened before and after the Global Economic Crisis. In other words, the increasing of import of dried cassava in the world did not affect positively to the growth effect in some period; especially during the Global Economic Crisis.

The commodity composition effect in Figure 3 shows that during the Global Economic Crisis at 2008-2009, all countries had the positive values of dried cassava commodity composition. The positive value means that countries had concentrated its export on dried cassava commodities because the growth rates of dried cassava are higher than the world average. During this period, all countries in period 1 focus on exported dried cassava, because the country focus on commodities that grew relatively fast between period 1 and period 2. It can be concluded that dried cassava has the high opportunity in survive during the Global Economic Crisis. It also can be seen that at period 2014-2015, commodity composition effect of dried cassava had increasing tendency, which means that the concentrated export on dried cassava commodities had the high growth rate than the world average.

Figure 4 shows the unexplained residual (competitiveness effect) which indicates the country performance in maintaining its share of the exports of dried cassava. During the global crisis 2008-2009, the country that succesfully maintained market share in all markets for dried cassava were Thailand and Vietnam. Thailand and Vietnam increased the market shares in all markets for dried cassava, so the competitiveness has increased. But Indonesia failed to maintain the same market share in all markets for commodity of dried cassava, which is indicating the competitiveness of Indonesia in this period has decreased.

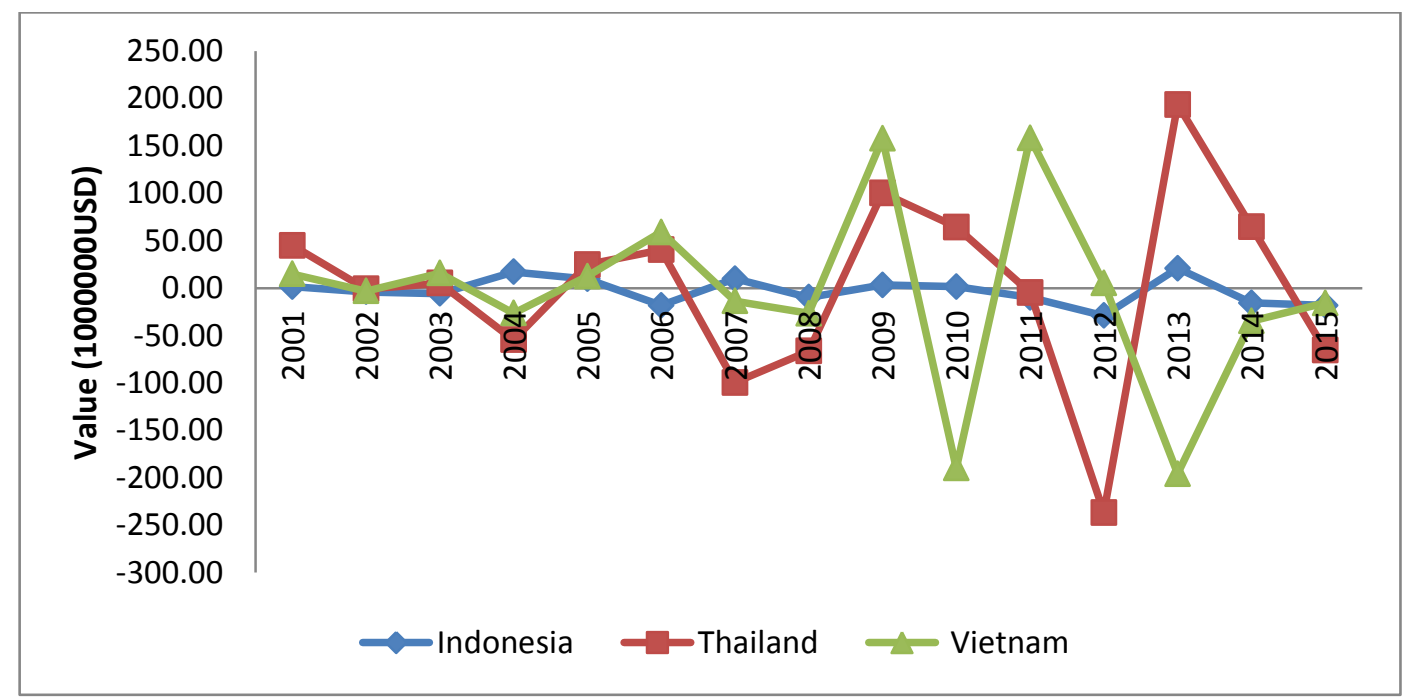

Figure 4. Competitiveness Effect from CMS

\section{a. Period 2000 to 2007}

In period 2000-2007 is the time after the Financial Crisis in Asia and before the Global Economic Crisis. The results of constant market share show in table 1. All countries have positive export change during that period, which means that Indonesia, Thailand, and Vietnam maintained their share in the world market.

The growth effect also show the positive value, which is mean that the part of the growth of cassava have positive attributed to the overall rise in world exports. The commodity composition effect show that after the Financial Crisis in Asia and before the Global Economic Crisis, all countries have the positive values of dried cassava commodity composition, which is mean that countries have concentrated its export on dried cassava commodities because the growth rates of dried cassava demand relative quickly.

The competitiveness effect captures the diference between the actual export growth and the growth that would have occurred. The export shares remained constant. A positive value means an increase in competitiveness. After the Financial Crisis in Asia and before the Global Economic 
Crisis, the competitiveness effect from all countries are positive. This means that dried cassava from all countries have an increasing in competitiveness.

Table 1. Constant Market Share Analysis in 2000-2007

\begin{tabular}{|c|c|c|c|c|c|c|}
\hline \multicolumn{7}{|c|}{$2000-2007$} \\
\hline \multirow[b]{2}{*}{ Indicator } & \multicolumn{2}{|c|}{ Indonesia } & \multicolumn{2}{|c|}{ Thailand } & \multicolumn{2}{|c|}{ Vietnam } \\
\hline & $\begin{array}{c}\text { Million } \\
\text { USD }\end{array}$ & $\%$ & Million USD & $\%$ & $\begin{array}{c}\text { Million } \\
\text { USD }\end{array}$ & $\%$ \\
\hline Export Change & 20.49 & 100.00 & 365.31 & 100.00 & 162.79 & 100.00 \\
\hline Growth Effect & 12.43 & 60.65 & 220.16 & 60.27 & 28.98 & 17.80 \\
\hline Commodity Composition & 5.86 & 28.60 & 103.83 & 28.42 & 13.67 & 8.40 \\
\hline Competitiveness Effect & 2.20 & 10.75 & 41.32 & 11.31 & 120.15 & 73.80 \\
\hline
\end{tabular}

Source: United Nations Commodity Trade (2017)

b. Period 2008 to 2009

The Global Economic Crisis at 2008-2009 affected positively the export changes, which is mean that Indonesia, Thailand, and Vietnam maintained their share in the world market during the crisis. Different with the export changes, the growth effects show the negative values for all countries. It means that the part of the growth of dried cassava has negative attributed to the overall rise in world exports.

During the crisis, dried cassava had the positive value of commodity composition effect, which meant that countries have concentrated its export on dried cassava commodities because the growth rates of dried cassava import value relative quickly during the crisis. Although the import relative growth during the crisis and the import in the world of dried cassava are increasing, those still made negative the growth effect. This condition is happening because the import of another commodities are decreasing during the crisis, so that the world import decreasing. It can be concluded, that during the crisis, according the demand and import of dried cassava that increase, dried cassava export to the world still can survive. This statement can be also supported by looking the competitiveness effect during the Global Economic Crisis from all countries are positive. This means that dried cassava from all countries during the crisis have an increasing in competitiveness. So the crisis makes the country increasingly competing in exporting.

Table 2. Constant Market Share Analysis in 2008-2009

\begin{tabular}{|c|c|c|c|c|c|c|}
\hline \multicolumn{7}{|c|}{$2008-2009$} \\
\hline \multirow[b]{2}{*}{ Indicator } & \multicolumn{2}{|c|}{ Indonesia } & \multicolumn{2}{|c|}{ Thailand } & \multicolumn{2}{|c|}{ Vietnam } \\
\hline & $\begin{array}{l}\text { Million } \\
\text { USD }\end{array}$ & $\%$ & $\begin{array}{l}\text { Million } \\
\text { USD }\end{array}$ & $\%$ & $\begin{array}{c}\text { Million } \\
\text { USD }\end{array}$ & $\%$ \\
\hline Export Change & 4.46 & 100 & 127.65 & 100 & 166.66 & 100 \\
\hline Growth Effect & $(4.79)$ & $(107.47)$ & (110.19) & $(86.32)$ & $(36.21)$ & $(21.73)$ \\
\hline Commodity Composition & 5.99 & 134.26 & 137.66 & 107.84 & 45.24 & 27.14 \\
\hline Competitiveness Effect & 3.26 & 73.21 & 100.18 & 78.48 & 157.64 & 94.58 \\
\hline
\end{tabular}

Source: United Nations Commodity Trade (2017)

\section{c. Period 2010 to 2015}

After the Global Economic Crisis, Indonesia has negative export change. This can be happening because the quantity of exports dried cassava from Indonesia to the world are tendency decreasing this period. Different with Thailand and Vietnam, this two countries have the positive value of export change. That is mean, countries maintained their share in the world market after the crisis. The growth effect also shows the positive value, which is indicating that after the Global Economic Crisis, the part of the growth of cassava have positive attributed to the overall rise in world exports. The same positive value also happening to the commodity composition effect. After the Global Economic Crisis, all countries have concentrated its export on dried cassava commodities because the growth rate of dried cassava demand tends to increase quickly.

After the Global Economic Crisis, the competitiveness effect from all countries are negative, which means dried cassava from all countries have a decreasing in competitiveness. This is happening because after the crisis, the total import of dried cassava in the world is not as high as before the crisis. Before the crisis, the increasing of total dried cassava import is $169 \%$. After the 
crisis, the increasing of total dried cassava import is 95\% (FAO, 2017).

Table 3. Constant Market Share Analysis in 2010-2015

\begin{tabular}{|c|c|c|c|c|c|c|}
\hline \multicolumn{7}{|c|}{$2010-2015$} \\
\hline \multirow[b]{2}{*}{ Indicator } & \multicolumn{2}{|c|}{ Indonesia } & \multicolumn{2}{|c|}{ Thailand } & \multicolumn{2}{|c|}{ Vietnam } \\
\hline & Million USD & $\%$ & $\begin{array}{l}\text { Million } \\
\text { USD }\end{array}$ & $\%$ & Million USD & $\%$ \\
\hline Export Change & (29.98) & 100.00 & 724.09 & 100.00 & 187.23 & 100.00 \\
\hline $\begin{array}{l}\text { Growth Effect } \\
\text { Commodity }\end{array}$ & 2.10 & $(7.02)$ & 52.51 & 7.25 & 13.62 & 7.27 \\
\hline Composition & 29.42 & $(98.14)$ & 734.09 & 101.38 & 190.40 & 101.69 \\
\hline Competitiveness Effect & $(61.51)$ & 205.16 & $(62.51)$ & $(8.63)$ & $(16.79)$ & $(8.97)$ \\
\hline
\end{tabular}

Source: United Nations Commodity Trade (2017)

\section{CONCLUSION AND SUGGESTION}

The result of Constant Market Share (CMS) shows Indonesia, Thailand, and Vietnam maintained their share in the world market during the Global Economic Crisis, because the growth rates of dried cassava import relative quickly during the crisis. After the Global Economic Crisis, the competitiveness effect from all countries are negative. That means dried cassava from all countries have a decreasing in competitiveness. The crisis makes the import of other commodities are decreased. But, it did not happen for dried cassava. The dried cassava export to the world survived during this crisis. This also can be a measure, that Indonesia should be more focus to export dried cassava, since this commodity is able to survive during the crisis.

\section{ACKNOWLEDGEMENT}

Primarily I express my greatest appreciation and my foremost gratitude go to all of my advisors; Professor Wen-Chi Huang, Ph.D., Wen-I Chang, Ph.D., and Dr. Ir. Suhartini, MP., for their patience, guidance, and dedication for this study. My deeply gratitude also Hsing-Hua Chang, Ph.D. and Hery Toiba, Ph.D., for their suggestions and supports.

\section{REFERENCES}

Fagerberg, J. And G. Soll. 1985. The Method Of Constant-Market Shares Analysis Revisi Ted. Discussion Paper Central Bureau Of Statistics 9: 1-18.
Ham, L. H., H. Kim, N. T. T. Mai, N. B. Mai, and R. Howeler. 2016. The cassava revolution in Vietnam. World Congress on Root and Tubercrops 1-33.

Nahro, D. 2014. Competitiveness of Processed Dry Cassava Indonesia in International Market. Master Thesis, Agribusiness Department, Agricultural Institute Bogor.

Piyachomkwan, K. and M. Tanticharoen. 2011. Cassava Industry in Thailand: Prospects. The Journal of the Royal Institute of Thailand 3: 160-170.

Suwandi. 2016. Outlook of cassava 2016. Jakarta: Pusat Data dan Sistem Informasi Pertanian Kementerian Pertanian. 59 pages.

Vignes, L. A. D. and K. Smith. 2005. Measuring The Competitiveness of The Trinidad \& Tobago Economy. The Caribbean Centre for Monetary studies (CCMS) Conference 136.

Food and Agriculture Organization. n.d. Retrieved on Apr. 30, 2017, from the World Wide Web: http://faostat3.fao.org/

United Nations Comodity Trade. n.d. Retrieved on Apr. 30, 2017, from the World Wide Web: http://comtrade.un.org/data/ 